\title{
Effect of different doses of pregabalin on skeletal muscle ischaemia-reperfusion injury in rats
}

\author{
Ozturk $\mathrm{L}^{*}$, Dogan $\mathrm{HT}^{2 *}$, Kilicarslan $\mathrm{A}^{2}$, Aydin $\mathrm{ME}^{3}$, Ozer $\mathrm{A}^{4}$, Demirtas $\mathrm{H}^{4}$, Kilic $\mathrm{Y}^{4}$, Iriz E $\mathrm{E}^{4}$, \\ Kucuk $\mathrm{A}^{5}$, Bayraktar $\mathrm{AC}^{6}$, Kavutcu $\mathrm{M}^{6}$, Arslan $\mathrm{M}^{3}$ \\ Department of Anaesthesiology and Reanimation, Yildirim Bayazit University Medical Faculty, Ankara-Turkey. \\ mustarslan@gmail.com
}

\begin{abstract}
AIM/INTRODUCTION: Analgesic, anti-inflammatory and anti-apoptotic effects of pregabalin have been shown previously. In this study, we investigated the protective effect of different doses of pregabalin on skeletal muscle IR injury in rats.

MATERIALS AND METHODS: 24 rats were randomly divided into 4 groups (Control, Ischaemia-Reperfusion (IR), IR-Pregabalin 50 mg, IR-Pregabalin $200 \mathrm{mg}$ ). Following IR, serum Ischemia Modified Albumin (IMA) and tissue Paraoxonase (PON) were studied and gastrocnemius muscle tissue was removed for histopathologic examination. RESULTS: Interstitial inflammation was higher in the IR group than in the control and Pregabalin $200 \mathrm{mg}$ groups ( $p=0.037, p=0.037$, respectively). Congestion was higher in the IR group than in the control, Pregabalin 50 and $200 \mathrm{mg}$ groups $(p=0.001, p=0.004, p=0.004$, respectively). PON was lower in the IR group than in the Control, Pregabalin 50 and $200 \mathrm{mg}$ groups $(p=0.001, p=0.007, p=0.015$, respectively). IMA was higher in the IR group than in the Control, Pregabalin 50 and $200 \mathrm{mg}$ groups $(p<0.0001$, all).

CONCLUSION: We think that administration of pregabalin, more prominent at $200 \mathrm{mg}$, can reverse the injury that occurs in the skeletal muscle of IR-induced rats. Pregabalin can be safely used for analgesia in cases of IR (Tab. 2, Fig. 9, Ref. 41). Text in PDF www.elis.sk.

KEY WORDS: hind limb ischemia reperfusion, pregabalin, histopathology, IMA, PON.
\end{abstract}

\section{Introduction}

Cellular damage after reperfusion of previously viable ischemic tissues in lower extremity is a common and critical clinical incident. If blood flow is re-established after reperfusion, substances produced as a result of metabolites' oxidation are spread throughout the body by systemic circulation. Oxygen free radicals are the most important and toxic substance produced in various clinical conditions (1). What all of these clinical situations have in common is either hypoxic microenvironments followed by reoxygenation or ischaemic microenvironments followed by reperfusion. As reperfusion progresses, generally systemic inflammatory response syndrome and multiple organ failure (kidney, respiratory and circulatory system, etc.) follow local edema and muscle necrosis (2-6).

${ }^{1}$ Department of Anaesthesiology and Reanimation, Yildirim Bayazit University Medical Faculty, Ankara, Turkey, ${ }^{2}$ Department of Pathology, Yildirim Bayazit University Medical Faculty, Ankara, Turkey, ${ }^{3}$ Department of Anaesthesiology and Reanimation, Gazi University Medical Faculty, Ankara, Turkey, ${ }^{4}$ Department of Cardiovascular Surgery, Gazi University Medical Faculty, Ankara, Turkey, ${ }^{5}$ Department of Physiology, Dumlupinar University Medical Faculty, Kütahya, Turkey, and ${ }^{6}$ Department of Medical Biochemistry, Gazi University Medical Faculty, Ankara, Turkey

*These authors contributed equally to this work

Address for correspondence: M. Arslan, Department of Anaesthesiology and Reanimation, Gazi University Medical Faculty, Ankara, Turkey.
Pregabalin is a structural analog of gamma-aminobutyric acid (GABA) (7). Currently, pregabalin is indicated for the management of neuropathic pain associated with diabetic peripheral neuropathy $(8,9)$, postherpetic neuralgia $(10,11)$, and management of fibromyalgia $(12,13)$. In addition, pregabalin is used frequently in the treatment of anxiety (14). It has a distinct mechanism of action relative to other anti-anxiety agents $\left(\alpha_{2} \delta\right.$ binding at presynaptic voltage dependent calcium channels leading to inhibition of excitatory neurotransmission). Pregabalin does not interact with liver enzymes and $95 \%$ of it is excreted by kidneys. Besides these clinical indications, it has some new properties that we need to focus on. Pregabalin has been used to protect against I/R injury in many organs $(15,16)$.

Benefits of pregabalin use to prevent local and distal tissue injury due to I/R has been well documented so far. However, not much is known about the protective effect of low and high doses of pregabalin on $\mathrm{I} / \mathrm{R}$ injury. The primary aim of this study was to investigate the effect of low and high doses of pregabalin on skeletal muscle $\mathrm{I} / \mathrm{R}$ injury in rats.

\section{Materials and methods}

\section{Animals and experimental protocol}

This study was carried out in Gazi University Physiology Laboratory with the approval of the Ethics Committee of Experimental Animals of our university. All of the procedures were performed 
according to accepted standards of Guide for the Care and Use of Laboratory Animals.

In our study, 24 Wistar Albino rats weighing between 250 and $300 \mathrm{~g}$, raised under the same environmental conditions, were used. The rats were kept under $20-21{ }^{\circ} \mathrm{C}$ at cycles of 12-hour daylight and 12-hour darkness and had free access to food until 2 hours before the anesthesia procedure. The animals were randomly separated into four groups, each containing 6 rats. Midline laparatomy was done under general anesthesia.

\section{Control group}

A midline laparotomy was performed without any extra surgical intervention. After 2 hours of follow-up blood and tissue samples were collected and animals were then sacrificed.

\section{I/R group}

Midline laparotomy was performed in the same way. Infrarenal aorta was clamped for 2 hours. The clamp was removed and then reperfusion was started. Reperfusion lasted for two more hours. In the end, after blood and tissue sampling, the rats were sacrificed.

\section{I/R group with pregabalin $50 \mathrm{mg}$}

Similiar steps were followed as mentioned above but in addition to the procedure pregabalin was given $\left(50 \mathrm{mg} \cdot \mathrm{kg}^{-1}\right)$ intraperitoneally for 30 minutes before ischemia period. After collecting blood and tissue samples, rats were sacrificed at the end of twohour reperfusion period.

\section{I/R group with pregabalin $200 \mathrm{mg}$}

Similiar steps were followed as mentioned above but in addition to the procedure, pregabalin was given $\left(200 \mathrm{mg} \cdot \mathrm{kg}^{-1}\right)$ intraperitoneally for 30 minutes before ischemia period. After collecting blood and tissue samples, rats were sacrificed at the end of two-hour reperfusion period.

Rats were anesthetized with ketamine (100 mg. $\mathrm{kg}^{-1}$, intraperitoneally) and intracardiac blood samples and tissue samples were collected.

A total of 25 muscle tissues including control and experimental cases were processed for paraffin sections. Formalin fixation, dehydration, clearing with xylene, paraffin wax infiltration and blocking steps were performed, respectively. Sections of fourmicron thickness were taken from paraffin blocks. The presence of interstitial inflammation, edema, congestion, atrophy, necrosis and increased fat tissue are evaluated according to hematoxylineosin sections. The presence of fibrosis was evaluated according to Masson's Trichrome staining.

\section{Paraoxonase activity assay}

Paraoxonase activity was determined spectrophotometrically at $25^{\circ} \mathrm{C}$ with paraoxon (diethyl p-nitrophenyl phosphate) $(1 \mathrm{mM})$ in $50 \mathrm{mM}$ glycine/ $\mathrm{NaOH}(\mathrm{pH} 10.5)$ containing $1 \mathrm{mM} \mathrm{CaCl}_{2}$. The enzyme assay was based on the estimation of p-nitrophenol at $412 \mathrm{~nm}$. The molar extinction coefficient of p-nitrophenol (e = $18,290 \mathrm{M}^{-1} \mathrm{~cm}^{-1}$ at $\mathrm{pH} 10.5$ ) was used to calculate enzyme activity (17). One enzyme unit was defined as the amount of enzyme that catalyzes the hydrolysis of $1 \mu \mathrm{mol}$ of substrate at $25^{\circ} \mathrm{C}(18)$.

\section{Ischemia-modified albumin Asssay}

Ischemia-modified albumin (IMA) was determined by a manual colorimetric assay described by Bar-Or et al (19) and called the $\mathrm{Co}(\mathrm{II})$-albumin binding assay. This method consists of adding a known amount of exogenous Co(II) to a plasma sample and measuring unbound Co(II) colorimetrically using dithiothreitol (DTT). The results are given in absorbance units (ABSU).

\section{Results}

The histopathological parameters of interstitial inflammation, atrophy, increase in fat tissue, and congestion were significantly different between the groups $(p=0.040, p=0.001, p=0.023, p$ $=0.003$, respectively). Interstitial inflammation was significantly higher in the IR group than in the control and Pregabalin $200 \mathrm{mg}$ groups ( $p=0.037, p=0.037$, respectively). Congestion was significantly higher in the IR group than in the control, Pregabalin 50 and $200 \mathrm{mg}$ groups $(\mathrm{p}=0.001, \mathrm{p}=0.004, \mathrm{p}=0.004$, respectively). Atrophy was higher in all groups compared to the control group ( $\mathrm{p}=0.001, \mathrm{p}<0.0001, \mathrm{p}=0.003$, respectively). Fat tissue increase was significantly higher in the IR group compared to the control group $(p=0.003)$ (Tab. 1, Figs 1-5). Collagen increase was detected with Masson trichrome stain (Figs 6-9).

PON was significantly lower in the IR group than in the Control, Pregabalin 50 and $200 \mathrm{mg}$ groups $(\mathrm{p}=0.001, \mathrm{p}=0.007, \mathrm{p}$ $=0.015$, respectively). PON was found similar among the other groups (Tab. 2).

IMA was significantly higher in the IR group than in the Control, Pregabalin 50 and $200 \mathrm{mg}$ groups ( $<<0.0001$, all). IMA was found similar among the other groups (Tab. 2).

Tab. 1. Rat muscle tissue histopathological findings (Mean \pm SD).

\begin{tabular}{lcccc}
\hline & $\begin{array}{c}\text { Group C } \\
(\mathrm{n}=6)\end{array}$ & $\begin{array}{c}\text { Group IR } \\
(\mathrm{n}=6)\end{array}$ & $\begin{array}{c}\text { Group IR-P50 } \\
(\mathrm{n}=6)\end{array}$ & $\begin{array}{c}\text { Group IR-P200 } \\
(\mathrm{n}=6)\end{array}$ \\
\hline Interstitial edema & $0.00 \pm 0.00^{*}$ & $0.50 \pm 0.22$ & $0.33 \pm 0.22$ & $0.00 \pm 0.00$ \\
Interstitial inflammation & $0.00 \pm 0.00$ & $0.33 \pm 0.17$ & $0.17 \pm 0.17$ & $0.17 \pm 0.17$ \\
Fibrosis & $0.00 \pm 0.00$ & $0.33 \pm 0.17$ & $0.17 \pm 0.17$ & $0.00 \pm 0.00$ \\
Necrosis & $0.00 \pm 0.00$ & $0.00 \pm 0.00$ & $0.00 \pm 0.00$ & $0.00 \pm 0.00$ \\
Atrophy & $0.00 \pm 0.00$ & $1.00 \pm 0.26 \&$ & $1.17 \pm 0.17 \&$ & $0.83 \pm 0.17 \&$ \\
Fat tissue increase & $0.00 \pm 0.00^{*}$ & $0.83 \pm 0.17$ & $0.50 \pm 0.22$ & $0.33 \pm 0.21$ \\
Congestion & $0.00 \pm 0.00^{*}$ & $0.83 \pm 0.17$ & $0.17 \pm 0.17 *$ & 0.001 \\
\hline
\end{tabular}

$\mathrm{p}^{* *}$ : Kruskal-Wallis test significance level $\mathrm{p}<0.05, \& \mathrm{p}<0.05$ : Compared with Control group; * $\mathrm{p}<0.05$ : Compared with group IR 


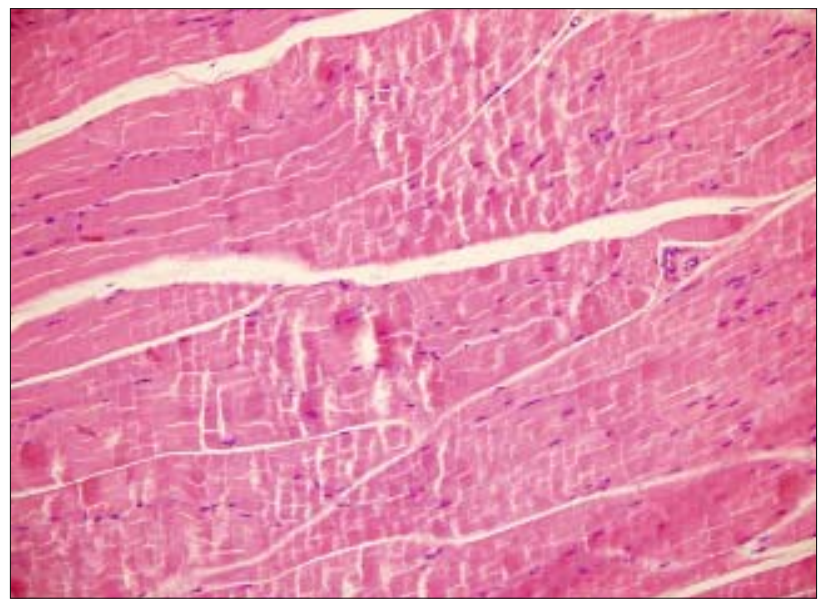

Fig. 1. Control Group normal muscle tissue (H\&Ex200).

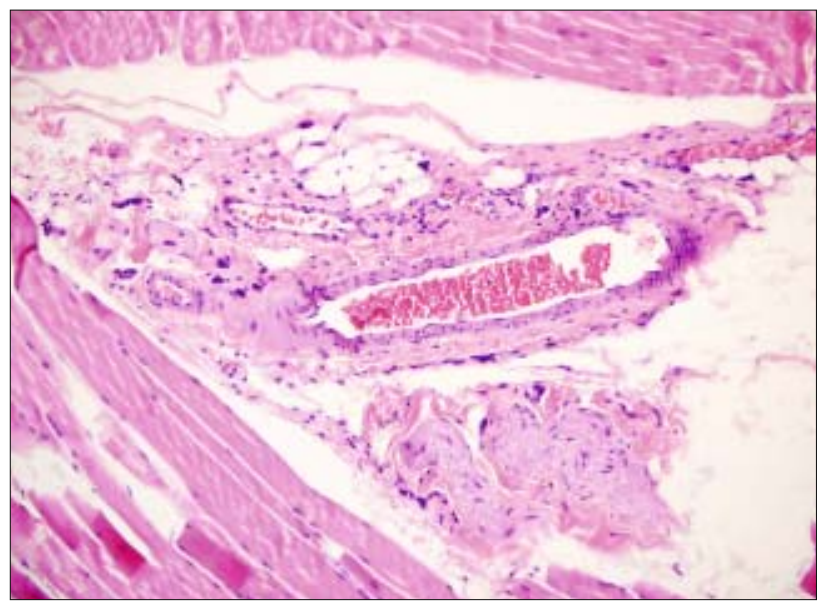

Fig. 2. Ischemia-reperfusion Group muscle tissue: atrophy, increase in fat tissue, congestion (H\&Ex200).

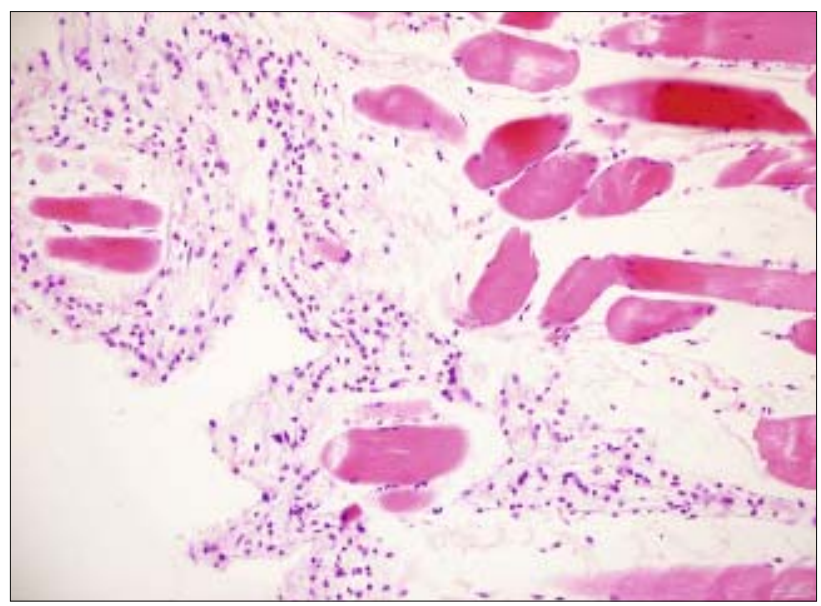

Fig. 3. Ischemia-reperfusion Group muscle tissue: atrophy, interstitial edema, inflammation (H\&Ex200).

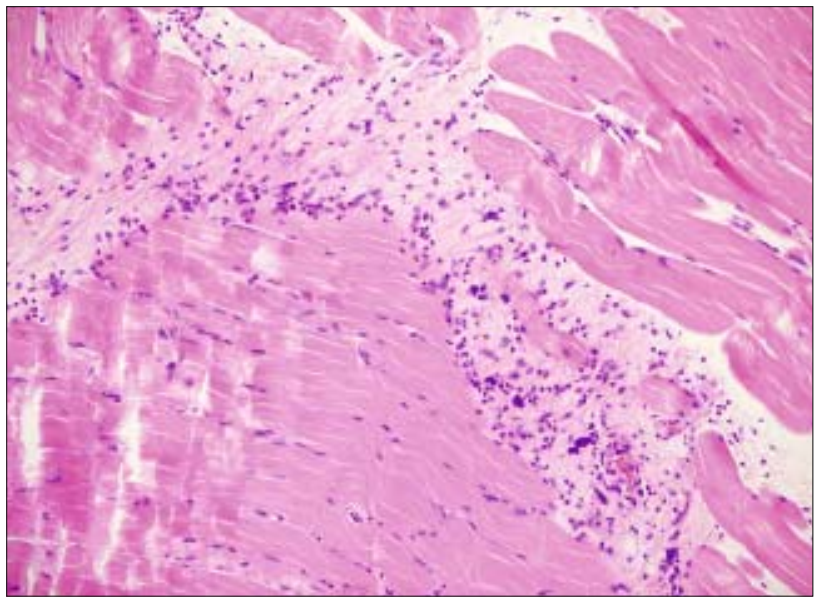

Fig. 4. Ischemia-reperfusion Pregabalin 50 mg Group muscle tissue: atrophy, interstitial edema, inflammation (H\&Ex200).

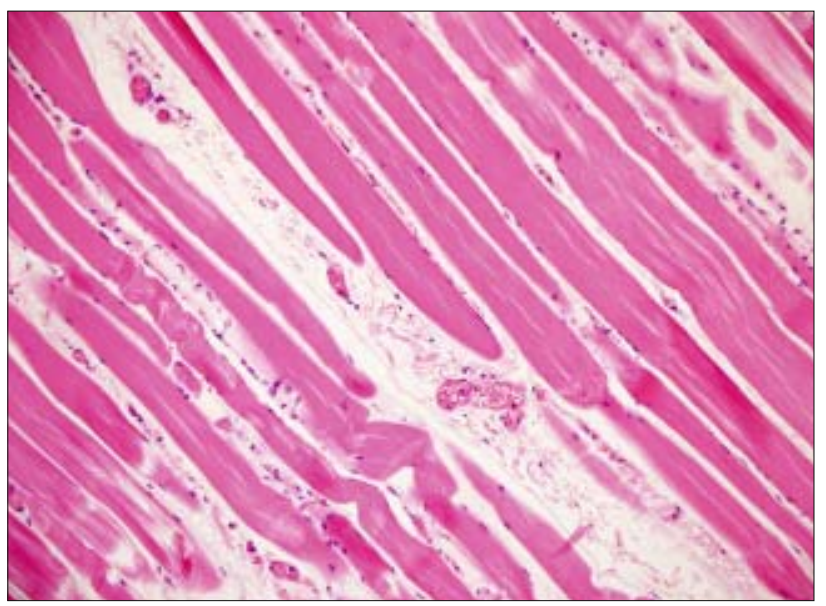

Fig. 5. Ischemia-reperfusion Pregabalin $200 \mathrm{mg}$ Group muscle tissue: minimal congestion, edema (H\&Ex200).

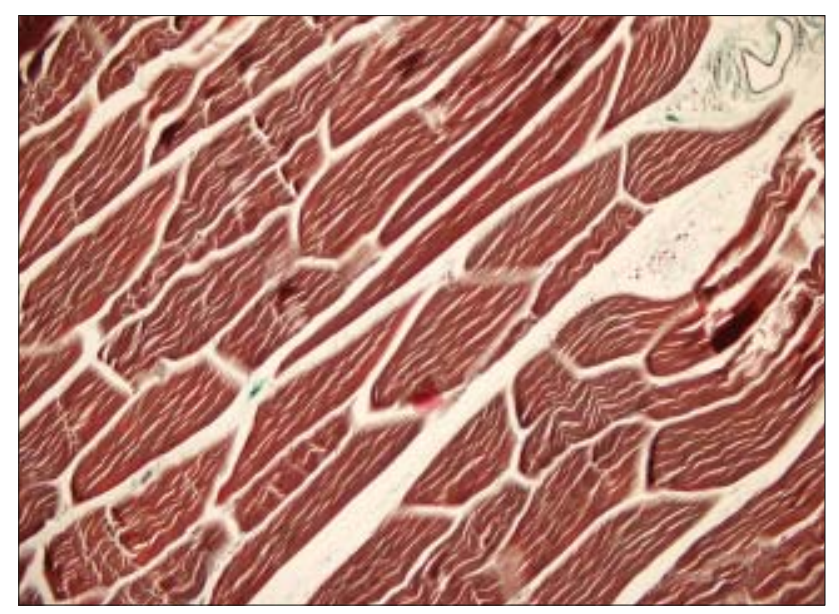

Fig. 6. Control Group normal muscle tissue (Masson Trichrome X200). 


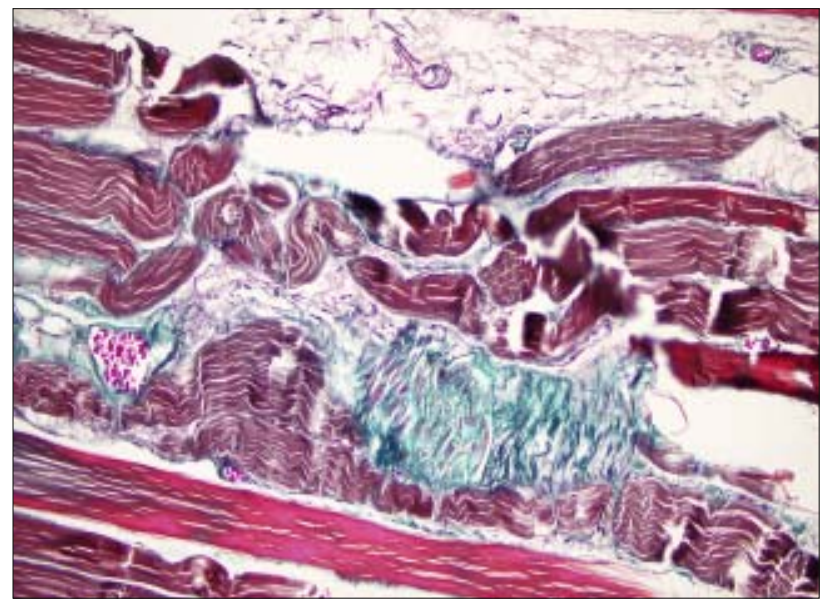

Fig. 7. Ischemia-reperfusion Group muscle tissue: fibrosis and fatty tissue increase (Masson Trichromex200). (Muscle fibers red brown, fibrosis-connective tissue increase $=$ collagen increase green).

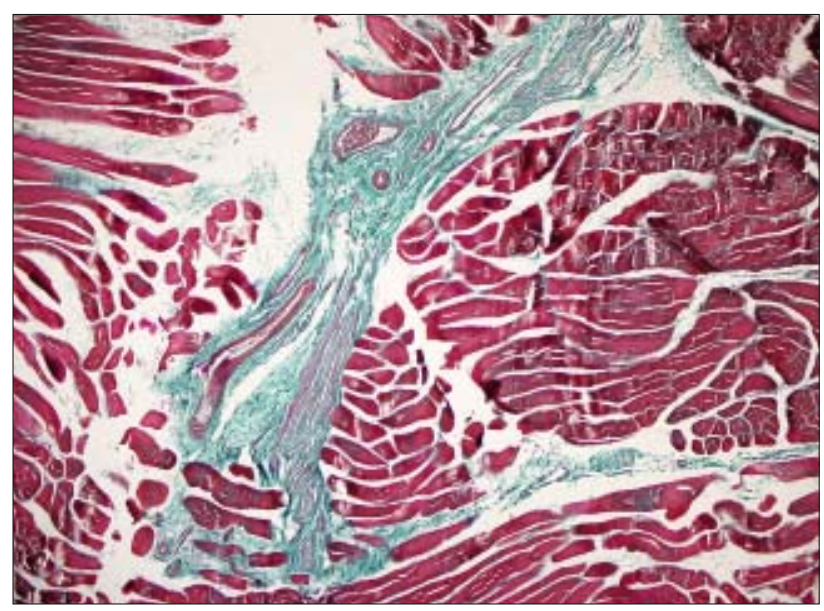

Fig. 8. Ischemia-reperfusion Pregabalin 50 mg Group muscle tissue: fibrosis (Masson Trichromex200).

\section{Discussion}

Ischemia followed by reperfusion in skeletal muscle causes an important clinical problem. Reperfusion followed by recanalization of the occluded blood vessels may also contribute to skeletal muscle injury. Free oxygen radicals released out after I/R injury have a remarkable mediator role in several organs' $I / R$ injuries (20-22). Recently, various approaches for protection from $I / R$ injury were supported with the help of various antioxidant molecules $(20,23-25)$.

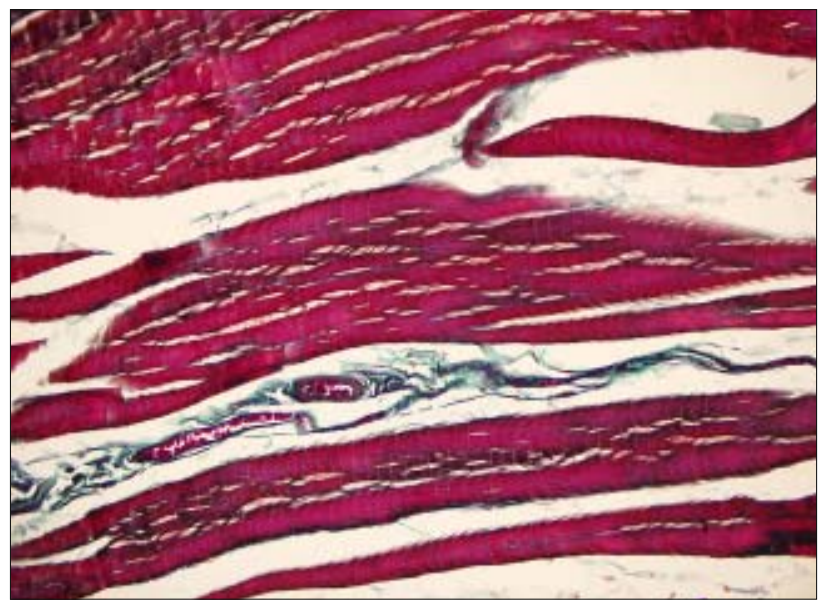

Fig. 9. Ischemia-reperfusion Pregabalin 200 mg Group muscle tissue (Masson Trichromex200).

Pregabalin is a structural analog of gamma-aminobutyric acid and has analgesic, anticonvulsant, anxiolytic and opioid-sparing effects. Pregabalin is a gabapentin derivative and has superior pharmacokinetic activity although it shows a similar effect (26). In animal studies, pregabalin, such as gabapentin, has also been shown to be effective in several models of neuropathic pain, incisional and inflammatory injury (27). There are studies showing that preoperative administration of pregabalin reduces acute postoperative pain, analgesic consumption and incidence of chronic neuropathic pain $(28,29)$.

In studies of Pregabalin, different methods of application have been used so far and there is no standard dose agreed for I/R injury treatment. Therefore, in our study we aimed to detect the protective effect of low and high doses of pregabalin on skeletal muscle ischemia-reperfusion injury in rats.

PON enzyme activity is critical for the physiological function of several key metabolic pathways, and plasma level of it is related with the pathogenesis of many diseases. In many clinical research studies, these findings have been reported (30-32). Oxidative stress especially appears in reperfusion after ischemia. Antioxidant defense system has a significant role in preventing the oxidative stress damage $(20,25,33,34)$. PON enzyme reduces oxidant activity to protect LDL from oxidation damage induced by free radical (35-37). In our study, PON was significantly lower in the IR group than in the Control, Pregabalin 50 and $200 \mathrm{mg}$ groups. However, PON level was similar among the other groups. Pregabalin increased PON enzyme activity.

Serum IMA levels may be a beneficial non-specific tissue ischemia biomarker (38). Active oxygen forms, particularly hydroxyl

Tab. 2. PON and IMA findings (Mean \pm SD).

\begin{tabular}{|c|c|c|c|c|c|}
\hline & $\begin{array}{c}\text { Group C } \\
(\mathrm{n}=6)\end{array}$ & $\begin{array}{c}\text { Group IR } \\
(\mathrm{n}=6)\end{array}$ & $\begin{array}{c}\text { Group IR-P50 } \\
(\mathrm{n}=6)\end{array}$ & $\begin{array}{c}\text { Group IR-P200 } \\
(\mathrm{n}=6)\end{array}$ & $\mathrm{p}^{* *}$ \\
\hline PON (IU/mg.protein) & $145.34 \pm 17.34 *$ & $58.22 \pm 3.61$ & $129.28 \pm 16.78^{*}$ & $122.94 \pm 13.28 *$ & 0.001 \\
\hline IMA ( $\triangle$ ABSU.un) & $0.29 \pm 0.04 *$ & $0.62 \pm 0.05$ & $0.36 \pm 0.04 *$ & $0.35 \pm 0.04 *$ & $<0.0001$ \\
\hline
\end{tabular}

$\mathrm{p}^{* *}$ : Kruskal-Wallis test significance level $\mathrm{p}<0.05,{ }^{*} \mathrm{p}<0.05$ : Compared with group IR 
radicals, might modify chemically human albumin and produce IMA (39). An increase in protein damage manifests as increased serum levels of IMA. It has been shown previously that IMA level estimated in blood serum sample has a prognostic value for acute ischemic stroke (40). Also, it is reported that IMA level increases in early ischemia and remains high (41). In our study, IMA was significantly higher in the IR group than in the Control, Pregabalin 50 and $200 \mathrm{mg}$ groups. However, IMA was similar among the other groups.

The histopathological examination found interstitial inflammation to be significantly higher in the IR group than in the control and Pregabalin $200 \mathrm{mg}$ groups; congestion was significantly higher in the IR group than in the control and Pregabalin $200 \mathrm{mg}$ groups. Also, atrophy was higher in all groups compared to the control group and fat tissue increase was significantly higher in the IR group compared to the control group. In addition, collagen increase was detected with Masson trichrome stain. These results indicate that pregabalin has a protective effect on skeletal muscle damage created with IR.

In conclusion, we found out that pregabalin increased the antioxidant ability and has a protective effect on skeletal muscle IR injury in rats. Also, evaluation of serum PON, IMA levels and histopathological findings of skeletal muscle tissue showed that pregabalin had valuable protective effects on skeletal muscle I/R injury; hence pregabalin can be acknowledged as a protective theraphy for skeletal muscle I/R injury. We think that administration of pregabalin, more prominent at $200 \mathrm{mg}$, can reverse the injury that occurs in the skeletal muscle of IR-induced rats. Pregabalin can be safely used for analgesia in cases of IR. To the best of our knowledge there is no preclinical study comparing the effect of different doses of pregabalin on skeletal muscle I/R Injury. As we could not investigate the long-term results of pregabalin treatment of skeletal muscle IR injury, we still think that these promising results should further be supported by more detailed studies with larger volumes.

\section{References}

1. Hensley K, Robinson KA, Gabbita SP et al. Reactive oxygen species, cell signaling, and cell injury. Free Radic Biol Med 2000; 15;28: 1456-1456.

2. Sirmali R, Armağan A, Öktem F, Uz E et al. Protective effects of erdosteine, vitamin $\mathrm{E}$, and vitamin $\mathrm{C}$ on renal injury induced by the ischemia-reperfusion of the hind limbs in rats. Turk J Med Sci 2015; 45 (1): 33-37.

3. Duru S, Koca U, Oztekin S et al. Antithrombin III pretreatment reduces neutrophil recruitment into the lung and skeletal muscle tissues in the rat model of biletaral lower limb and reperfusion: A pilot study. Acta Anaesthesiol Scand 2005; 49: 1142-1148.

4. Turchanyi B, Toth B, Racz I et al. Ischemia reperfusion injury of skeletal muscle after selective deafferantation. Physiol Res 2005; 54: 25-32.

5. Erer D, Özer A, Demirtaş H, Gönül II, Kara H, Arpaci H, Comu FM, Oktar GL, Arslan M, Küçük A. Effects of Alprostadil and Iloprost on Renal, Lung and Skeletal Muscle Injury Following Hind limb IschemiaReperfusion Injury in Rats. Drug Des Devel Ther 2016; 10: 2651-2658.
6. Erer D, Dursun AD, Oktar GL, Iriz E, Zor MH, Elmas C, Donmez T, Kirisci M, Comu FM, Arslan M. The effects of iloprost on lung injury induced by skeletal muscle ischemia-reperfusion. Bratisl Med J 2014; 115 (7): 405-410.

7. Martin L, Rabasseda X, Leeson P, Castaner J. Pregabalin. Drugs of the Future 1999; 24 (8): 862-870.

8. Satoh J, Yagihashi S, Baba M, Suzuki M, Arakawa A, Yoshiyama $\mathbf{T}$ et al. Efficacy and safety of pregabalin for treating neuropathic pain associated with diabetic peripheral neuropathy: a 14 week, randomized, double-blind, placebo-controlled trial. Diabet Med 2011; 28: $109-116$.

9. Tolle T, Freynhagen R, Versavel M, Trostmann U, Young J Jr. Pregabalin for relief of neuropathic pain associated with diabetic neuropathy: a randomized, double-blind study. Eur J Pain 2008; 12: 203-213.

10. Achar A, Chatterjee G, Ray T, Naskar B. Comparative study of clinical efficacy with amitriptyline, pregabalin, and amitriptyline plus pregabalin combination in postherpetic neuralgia. Indian J Dermatol Venereol Leprol 2010; 76: 63-65.

11. Barbarisi M, Pace M, Passavanti M, Maisto M, Mazzariello L, Pota V et al. Pregabalin and transcutaneous electrical nerve stimulation for postherpetic neuralgia treatment. Clin J Pain 2010; 26: 567-572.

12. Crofford L, Mease P, Simpson S, Young J Jr, Martin S, Haig G et al. Fibromyalgia relapse evaluation and efficacy for durability of meaningful relief (FREEDOM): a 6-month, double-blind, placebo-controlled trial with pregabalin. Pain 2008; 136: 419-431.

13. Ohta H, Oka H, Usui C, Ohkura M, Suzuki M, Nishioka K. A randomized, double-blind, multicenter, placebo-controlled phase III trial to evaluate the efficacy and safety of pregabalin in Japanese patients with fibromyalgia. Arthritis Res Ther 2012; 14: R217.

14. Pohl R, Feltner D, Fieve R, Pande A. Efficacy of pregabalin in the treatment of generalized anxiety disorder: double-blind, placebo-controlled comparison of BID versus TID dosing. J Clin Psychopharmacol 2005; 25: 151-158.

15. Kazanci B, Ozdogan S, Kahveci R, Gokce EC, Yigitkanli K, Gokce A, Erdogan B. Neuroprotective Effects of Pregabalin Against Spinal Cord Ischemia-Reperfusion Injury in Rats. Turk Neurosurg 2016. doi: 10.5137/1019-5149.JTN.17959-16.1.

16. Ben-Menachem E. Pregabalin pharmacology and its relevance to clinical practice. Epilepsia 2004; 45 (Suppl 6): 13-18.

17. Renault F, Chabriere E, Andrieu JP, Dublet B, Masson P, Rochu DJ. Chromatogr B 2006; 836, 15-21.

18. Turkes C, Soyut H, Beydemir S. Pharmacol Rep 2014; 66: 74-80.

19. Bar-Or D, Curtis G, Rao N, Bampos N, Lau E. Characterization of the $\mathrm{Co} 2+$ and $\mathrm{Ni2}+$ binding amino-acid residues of the $\mathrm{N}$-terminus of human albumin. An insight into the mechanism of a new assay for myocardial ischemia. Eur J Biochem 2001; 268: 42-47.

20. Yildiz F, Coban S, Terzi A, Ates M, Aksoy N, Cakir H et al. Nigella sativa relieves the deleterious effects of ischemia reperfusion injury on liver. World J Gastroenterol 2008; 14: 5204-5209. doi: 10.3748/wjg.14.5204.

21. Yuan GJ, Ma JC, Gong ZJ, Sun XM, Zheng SH, Li X. Modulation of liver oxidant-antioxidant system by ischemic preconditioning during ischemia/reperfusion injury in rats. World J Gastroenterol 2005; 11: 1825-1828.

22. Zhang SJ, Shi JH, Tang Z, Wu Y, Chen S. Protective effects of glycine pretreatment on brain-death donor liver. Hepatobiliary Pancreat Dis Int 2005; 4: 37-40. 
$417-422$

23. HassanKhabbar S, Cottart CH, Wendum D, Vibert F, Clot JP, Savouret JF et al. Postischemic treatment by trans-resveratrol in rat liver ischemiareperfusion: a possible strategy in liver surgery. Liver Transpl. 2008; 14: 451-459. doi: 10.1002/1t.21405.

24. Polat KY, Aydinli B, Polat O, Aydin U, Yazici P, Ozturk G et al. The protective effect of aprotinin and alpha-tocopherol on ischemia-reperfusion injury of the rat liver. Transplant Proc 2008; 40: 63-68. doi:10.1016/j. transproceed.2007.11.047.

25. Shen SQ, Zhang Y, Xiang JJ, Xiong CL. Protective effect of curcumin against liver warm ischemia/reperfusion injury in rat model is associated with regulation of heat shock protein and antioxidant enzymes. World $\mathrm{J}$ Gastroenterol 2007; 13: 1953-1961.

26. Ben-Menachem E. Pregabalin pharmacology and its relevance to clinical practice. Epilepsia 2004; 45 (Suppl 6): 13-18.

27. Gajraj NM. Pregabalin: its pharmacology and use in pain management. Anesth Analg 2007; 105: 1805-1815.

28. Zhang J, Ho KY, Wang Y. Efficacy of pregabalin in acute postoperative pain: a meta-analysis. Br J Anaesth 2011; 106: 454-462.

29. Buvanendran A, Kroin JS, Della Valle CJ, Kari M, Moric M, Tuman KJ. Perioperative oral pregabalin reduces chronic pain after total knee arthroplasty: a prospective, randomized, controlled trial. Anesth Analg 2010; 110: 199-207.

30. Litvinov D, Mahini H, Garelnabi M. Antioxidant and anti-inflammatory role of paraoxonase 1: implication in arteriosclerosis diseases. $\mathrm{N}$ Am J Med Sci 2012; 4 (11): 523-532.

31. Rosenblat M, Grunfeld O, Hayek T, Aviram M. Serum paraoxonase activity and the extent of lipid peroxidation are not affected by increased levels of human apolipoprotein A-I: studies in transgenic mice. Clin Chem Lab Med 2002; 40 (1): 9-14.

32. Younis A, Clower C, Nelsen D et al. The relationship between pregnancy and oxidative stress markers on patients undergoing ovarian stimulations. J Assist Reprod Genet 2012; 29 (10): 1083-1089.
33. Sener G, Tosun O, Sehirli AO, Kacma A, Arbak S, Ersoy Y et al. Melatonin and $\mathrm{N}$-acetylcysteine have beneficial effects during hepatic ischemia and reperfusion. Life Sci 2003; 72: 2707-2718. doi:10.1016/ S0024-3205(03)00187-5.

34. Tarpey MM, Wink DA, Grisham MB. Methods for detection of reactive metabolites of oxygen and nitrogen: in vitro and in vivo considerations. Am J Physiol Regul Integr Comp Physiol 2004; 286: 431-444.

35. Celik M, Gulcu F, Ozan G, Gursu MF. Paraoxonase and arylesterase activity levels in workers exposed to organic solvents. Turk J Biochem 2005; 30: 194-199. doi:10.1016/j.tibs.2005.02.008.

36. Yildirim A, Aslan S, Ocak T, Yildirim S, Kara F, Sahin YN. Serum paraoxonase/arylesterase activities and malondialdehyde levels in trauma patients. Eurasian J Med 2007; 39: 85-88.

37. Memisogullari R, Orhan N. Paraoxonase and cancer. Konuralp Tip Dergisi 2010; 2: 22-26.

38. Sbarouni E, Georgiadou $\mathbf{P}$, Voudris V. Ischemia modified albumin changes-review and clinical implications. Clin Chem Lab Med 2011; 49: $177-184$.

39. Roy D, Quiles J, Gaze DC et al. Role of reactive oxygen species on the formation of the novel diagnostic marker ischaemia modified albumin. Heart 2006; 92: 113-114.

40. Gunduz, S. Turdi, A. Menetese, S.C. Karahan et al. Ischemia modified albumin levels in cerebrovascular accidents. Am J Emerg Med 2011; 26: $874-878$.

41. Ertekin B, Kocak S, Defne Dundar $Z$ et al. Diagnostic value of ischemia-modified albumin in acute coronary syndrome and acute ischemic stroke. Pak J Med Sci 2013; 29 (4): 1003-1007.

Received February 2, 2017. Accepted March 3, 2017. 